\section{Variation of the intrinsic rock properties on Hoek-Brown failure criterion parameters}

Rudarsko-geološko-naftni zbornik

(The Mining-Geology-Petroleum Engineering Bulletin) UDC: 624.121

DOI: $10.17794 / \operatorname{rgn} .2021 .4 \cdot 7$

Original scientific paper

\author{
Sina Salajegheh'; Kourosh Shahriar ${ }^{2^{*}}$; Hossein Jalalifar ${ }^{3}$; Kaveh Ahangari ${ }^{1}$ \\ ${ }^{\prime}$ Department of Mining Engineering, Science and Research Branch, Islamic Azad University, Tehran, Iran. \\ ${ }^{2}$ Department of Mining and Metallurgy Engineering, Amirkabir University of Technology, Tehran, Iran. \\ ${ }^{3}$ Department of Petroleum Engineering, Shahid Bahonar University of Kerman, Kerman, Iran.
}

\begin{abstract}
The Hoek-Brown (H-B) criterion is one of the most commonly used rock failure criteria in recent years. This criterion includes a constant parameter called $m_{i}$ which is a fundamental parameter for estimating rock strength. Due to the importance of the $m_{i}$ parameter in the $\mathrm{H}-\mathrm{B}$ criterion, it is necessary to conduct comprehensive studies on various aspects of the effect of this parameter on the behavior of rocks. Therefore, in this study, using numerical simulation of the Triaxial Compressive Strength (TCS) tests in PFC-2D code, the effects of microscopic properties of different rocks on the H-B parameter $m_{i}$ have been studied. Based on the results of this study, it was found that the effects of micro-parameters on the H-B parameter $m_{i}$ can be different depending on the type of rock, however this parameter has an inverse relationship to the micro-parameters of bond tensile strength and bond fraction of the rocks. Also, the $m_{i}$ parameter increases with an increase in the micro-parameters of the friction coefficient, the friction angle, the particle contact modulus, and the contact stiffness ratio of rocks.
\end{abstract}

Keywords:

Hoek-Brown criterion; $m_{i}$ parameter; Triaxial Compressive Strength test; microscopic properties; PFC-2D

\section{Introduction}

Between all of the failure criteria presented, the HoekBrown (H-B) (1980) empirical criterion is one of the most well-known. This criterion has become an indispensable tool for rock engineers due to its simplicity, proper compatibility to laboratory data, as well as its applicability to rock masses, and it has been used successfully in various aspects of rock engineering in recent years (Merifield et al., 2006; Bagheripour and Hakimipour, 2009; Osgoui and Ünal, 2009; Sari, 2012; Shen et al., 2013; Feng and Jimenez, 2015; Bertuzzi et al., 2016; Jiang et al., 2016; Sun et al., 2016; Wu et al., 2017; Peng et al., 2017; He et al., 2020).

Depending on the application, different types of H-B criterion have been proposed. The mathematical equation for an intact rock is expressed as follows (Hoek \& Brown, 1980a):

$$
\sigma_{1}=\sigma_{3}+\sigma_{c i}\left(m_{i} \frac{\sigma_{3}}{\sigma_{c i}}+1\right)^{0.5}
$$

Where:

$\sigma_{1}$ : the major principal stress,

$\sigma_{3}$ : the minor principal stress or confining pressure,

Corresponding author: Kourosh Shahriar

k.shahriar@aut.ac.ir $m_{i}:$ H-B material constant,

$\sigma_{c i}$ : the uniaxial compressive strength of the intact rock.

According to the H-B criterion, one of the parameters that has a significant effect on the failure of rocks is $m_{i}$, which is a dimensionless parameter. The strength parameter $m_{i}$ which is generally assumed to be a curve-fitting parameter to achieve the H-B failure envelope, can be determined by statistical evaluation of the results of experimental studies, linear or non-linear approaches (Hoek and Brown, 1980a; Hoek and Brown, 1980b; Hoek, 1983; Shah and Hoek, 1992; Colak and unlu, 2004), and its values are distributed from 7 to 35 depending on the rock material characteristics (Hoek, 2007). Due to its significance in $H-B$ failure criterion, many researchers have dedicated their studies to parameter $m_{i}$ (Colak and Unlu, 2004; Sari, 2010; Zhang et al., 2014; Wang and Shen, 2017; Aladejare and Wang, 2019; He et al., 2020; Wen et al., 2021), but it is still necessary to conduct more comprehensive studies about this parameter. Therefore, in the current study, by using numerical simulation of Triaxial Compressive Strength (TCS) tests on three different rock samples, it is attempted to investigate the effects of microscopic properties (micro-parameters) of different rocks on the H-B parameter $m_{i}$. In addition, the effects of micro-parameters on the failure envelope have been investigated. 
Table 1: Base values of micro-parameters from numerical samples

\begin{tabular}{|c|c|c|c|c|c|c|c|c|c|c|}
\hline \multirow{3}{*}{ Property } & \multicolumn{3}{|c|}{ Andesite } & \multicolumn{3}{|c|}{ Limestone } & \multicolumn{3}{|c|}{ Sandstone } & \multirow{3}{*}{ Unit } \\
\hline & \multirow{2}{*}{$\begin{array}{l}\text { Base } \\
\text { value }\end{array}$} & \multicolumn{2}{|c|}{ Range values } & \multirow{2}{*}{$\begin{array}{l}\text { Base } \\
\text { value }\end{array}$} & \multicolumn{2}{|c|}{ Range values } & \multirow{2}{*}{$\begin{array}{l}\text { Base } \\
\text { value }\end{array}$} & \multicolumn{2}{|c|}{ Range values } & \\
\hline & & Low & High & & Low & High & & Low & High & \\
\hline Density & 2450 & --- & --- & 2600 & --- & --- & 2450 & --- & --- & $\left(\mathrm{kg} / \mathrm{m}^{3}\right)$ \\
\hline Bonded fraction & 0.93 & 0.7 & 1 & 0.98 & 0.7 & 0.98 & 0.99 & 0.7 & 0.99 & --- \\
\hline Ec & 6.0 & 2 & 8 & 15.2 & 5 & 20 & 14.0 & 5 & 20 & $(\mathrm{GPa})$ \\
\hline $\mathrm{K}_{\mathrm{n}} / \mathrm{K}_{\mathrm{s}}^{*}$ & 1.7 & 0.5 & 2 & 2 & 1 & 2.5 & 1.7 & 1 & 2.5 & --- \\
\hline Friction coefficient & 0.45 & 0.2 & 0.8 & 0.8 & 0.4 & 1 & 0.3 & 0.3 & 0.9 & --- \\
\hline Cohesion & 33.5 & 10 & 40 & 64.5 & 20 & 80 & 82.0 & 40 & 100 & (MPa) \\
\hline Cohesion std & 3.35 & --- & 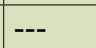 & 6.45 & --- & --- & 8.2 & --- & --- & $(\mathrm{MPa})$ \\
\hline Tensile strength & 5.0 & 1 & 15 & 12.6 & 1 & 15 & 4.5 & 1 & 15 & $(\mathrm{MPa})$ \\
\hline Tensile strength std & 0.5 & --- & --- & 1.26 & --- & --- & 0.45 & --- & --- & $(\mathrm{MPa})$ \\
\hline Friction angle & 5 & 0 & 30 & 15 & 0 & 20 & 5 & 0 & 30 & Degree \\
\hline
\end{tabular}

* Kn and Ks are normal and shear stiffness between grains respectively.

\section{Material and methods}

In the current study, the mechanical properties of three rock types namely andesite, limestone, and sandstone have been used to conduct investigations. Numerical simulations have been performed using Particle Flow Code 2D (PFC-2D), which is one of the most popular software based on the Discrete Element Method (DEM). Due to its high capability to simulate the mechanical behavior of different rocks, PFC-2D has been considered by many researchers and has been used in a wide range of numerical studies in recent years. (Potyondy and Cundall, 2004; Calvetti, 2008; Akram and Sharrock, 2010; Deisman et al., 2010; Mas Ivars et al., 2011; Asadi et al., 2012; Ghazvinian et al., 2012; Bahaaddini, Sharrock and Hebblewhite, 2013a; Bahaaddini, Sharrock and Hebblewhite, 2013b; Bahaaddini, Hagan, Mitra and Hebblewhite, 2014; Sarfarazi et al., 2014; Bahaaddini, Hagan, Mitra and Hebblewhite, 2016; Haeri and Sarfarazi, 2016; Bahaaddini, 2017; Gu et al., 2017; Cui et al., 2017; Hama et al., 2017; Lin et al., 2017; Sarfarazi et al., 2017; Jiang et al., 2018; Yang and Huang, 2018; Bahaaddini et al., 2019; Jafari Mohammadabadi et al., 2021).

In these studies, the numerical samples follow the ISRM recommendations, and the diameter and height of the samples were considered to be $54 \mathrm{~mm}$ and $115 \mathrm{~mm}$, respectively Figure 1. Before starting the analysis, it is essential to define the base values of the micro-parameters. The base values of the micro-parameters from each rock are given in Table 1, which is determined with a calibrating operation on the experimental data. For the calibration process, the mechanical behavior of the synthetic samples under the compression test was reproduced and compared with the experimental tests. In this paper, the TCS test has been used for calibrating the micro-properties of synthetic samples.

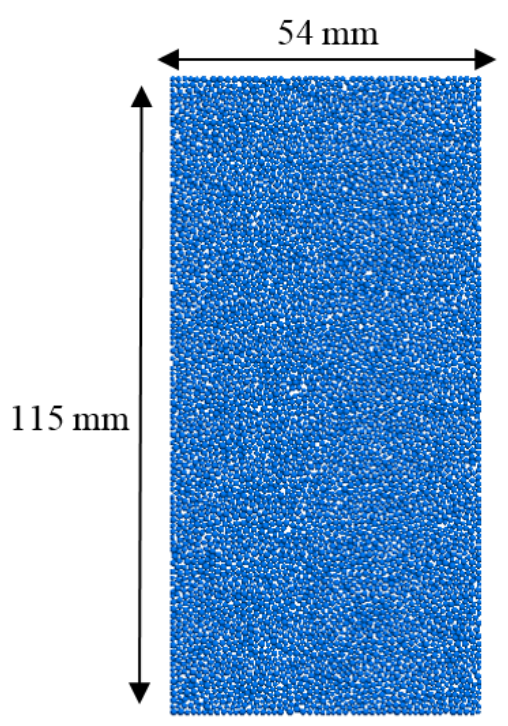

Figure 1: Geometry of PFC 2D model in TCS test

Also, to ensure the accuracy of the numerical results, the failure envelopes of one of the rock samples has compared with laboratory tests, which is shown in Figure 2. Moreover, in Table 2, the values of rock strength parameters in both numerical and laboratory modes are compared with each other. According to Figure 2 and Table 2, the values obtained from numerical models are very close to the laboratory values in all three rock samples. Therefore, it can be concluded that the created models are sufficiently accurate to perform more investigations.

\section{Results and discussion}

After validation and ensuring the accuracy of the answer provided by numerical simulations, to study the effect of micro-parameters on the $m_{i}$ parameter, seven fac- 


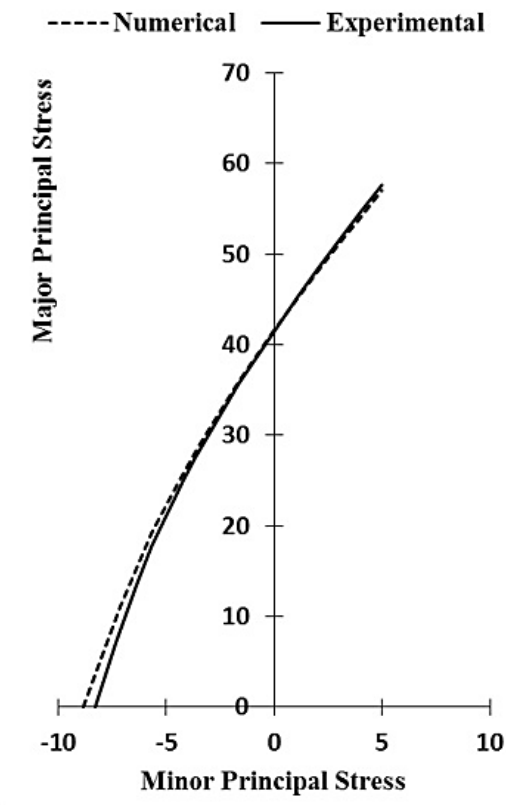

(A) Andesite.

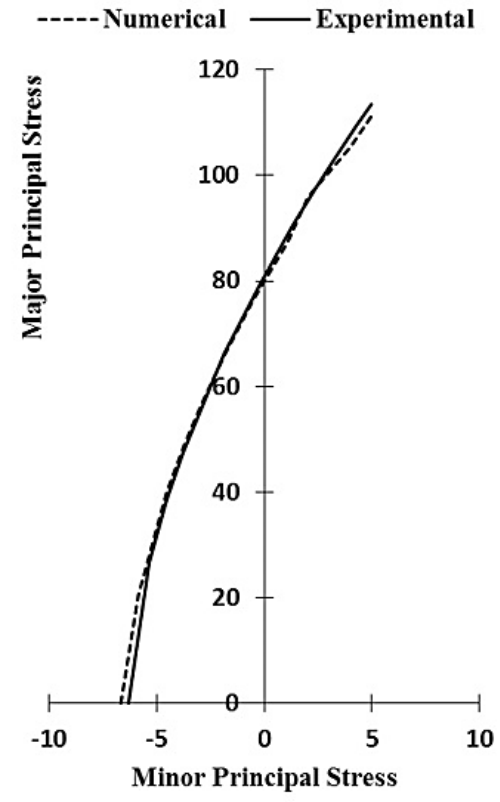

(B) Sandstone.

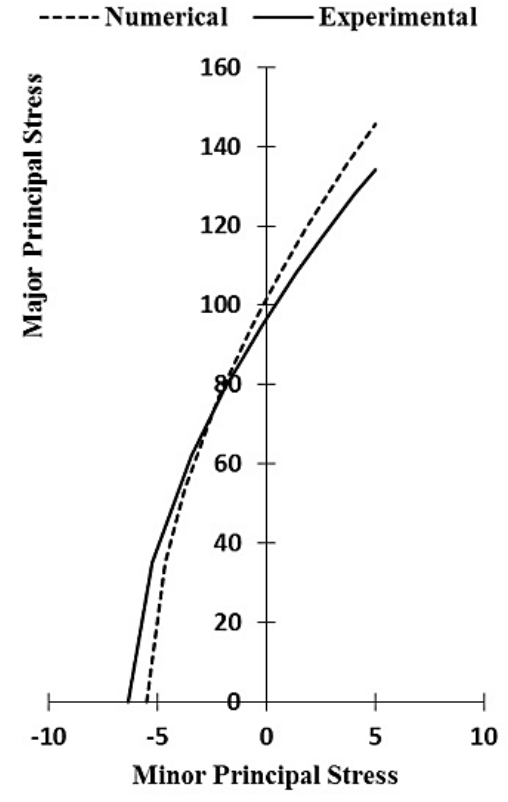

(C) Limestone.

Figure 2: Comparison of failure envelope of numerical and laboratory tests

Table 2: Comparison of numerical and experimental results

\begin{tabular}{|c|c|c|c|c|c|c|c|c|c|}
\hline \multirow[b]{2}{*}{ Rock } & \multicolumn{3}{|c|}{$m_{i}$} & \multicolumn{3}{|c|}{ C (MPa) } & \multicolumn{3}{|c|}{$\Phi\left(^{\circ}\right)$} \\
\hline & $\begin{array}{l}\text { Experi- } \\
\text { mental }\end{array}$ & Numerical & $\begin{array}{l}\text { STD* } \\
(\%)\end{array}$ & $\begin{array}{l}\text { Experi- } \\
\text { mental }\end{array}$ & Numerical & $\begin{array}{l}\text { STD } \\
(\%)\end{array}$ & $\begin{array}{l}\text { Experi- } \\
\text { mental }\end{array}$ & Numerical & $\begin{array}{l}\text { STD } \\
(\%)\end{array}$ \\
\hline Andesite & 5.00 & 6.47 & 2.94 & 12.35 & 12.42 & 0.56 & 31.40 & 35.22 & 12.16 \\
\hline Sandstone & 12.86 & 12.04 & 6.37 & 17.30 & 18.99 & 9.76 & 46.86 & 45.83 & 2.19 \\
\hline Limestone & 15.25 & 17.96 & 17.77 & 17.29 & 17.9 & 3.52 & 49.57 & 51.94 & 4.5 \\
\hline
\end{tabular}

*STD: standard deviation.

tors including bond tensile strength, bond cohesion, the friction coefficient, the friction angle, bond fraction, the particle contact modulus (Ec) and the contact stiffness ratio $(\mathrm{Kn} / \mathrm{Ks})$ have been selected. Since in current research the effects of micro-parameters on three different rocks have been evaluated, the results have been presented in three sections, which are discussed as follows.

\subsection{Andesite}

The results of the studies about the behavior of $m_{i}$ parameter in andesite rock are shown in Figure 3. According to Figure 3, it can be seen that the value of $m_{i}$ decreases with an increase in the amount of bond tensile strength, which changes from 0 to $15 \mathrm{MPa}$. By increasing the amount of particles bond cohesion, which has varied from 10 to $40 \mathrm{MPa}$, the $m_{i}$ parameter decreased firstly $(\mathrm{C}=20 \mathrm{MPa})$, then increased slightly and the changes became small. With an increase in the amount of the friction coefficient, which changed from 0.2 to $0.8, m_{i}$ also increased. The rate of these changes decreased between the values of 0.4 and 0.6 and then increased again as before. Changes in the values of the friction angle led to an increase in the $m_{i}$ parameter. The rate of these changes was smaller at lower angles. The $m_{i}$ parameter also decreased with an increase in the bond fraction which varied from 0.5 to 1 . Moreover, as the stiffness ratio increased, the $m_{i}$ parameter increased linearly. Also, with an increase in the value of the modulus of elasticity, the $m_{i}$ parameter increased slightly.

The effect of micro-parameters on the failure envelope of andesite rock are shown in Figure 4. According to Figure 4, it can be seen that the greatest impact of the tensile strength was on the minor stress. This micro-parameter also had an effect on the major stress of the rock, but its amount is small. The micro-parameters of cohesion, the friction coefficient and the friction angle caused the strength of the rock samples to increase. These micro-parameters only affected the major stress of the rock. Bond fraction lead to an increase in the value of the major and minor stress. The stiffness ratio and particle contact modulus also affected both stresses, but the greatest effect had occurred on the major stress.

\subsection{Sandstone}

The results of studies on sandstone samples are shown in Figures 5 and 6. Based on the results of Figure 5, it 


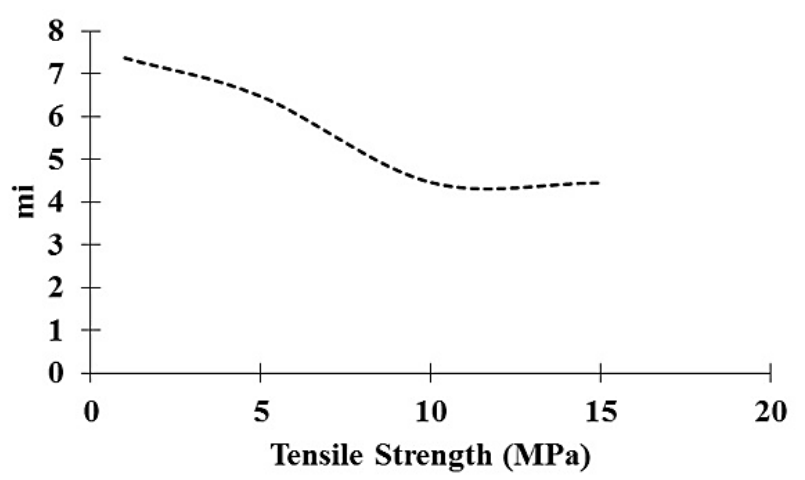

(a)

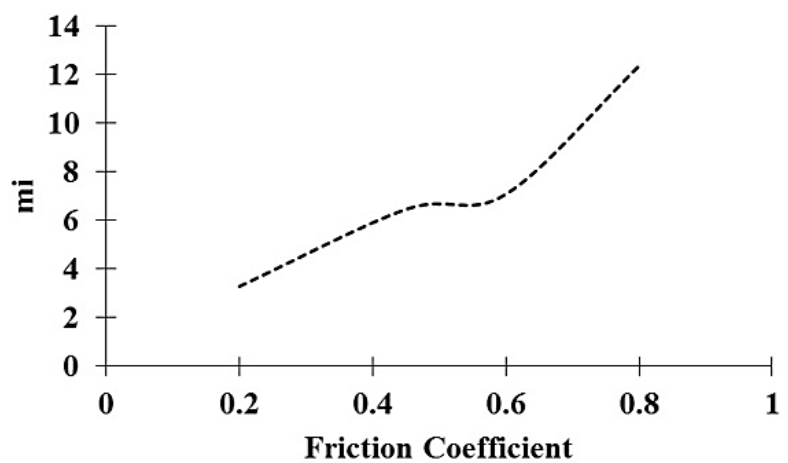

(c)

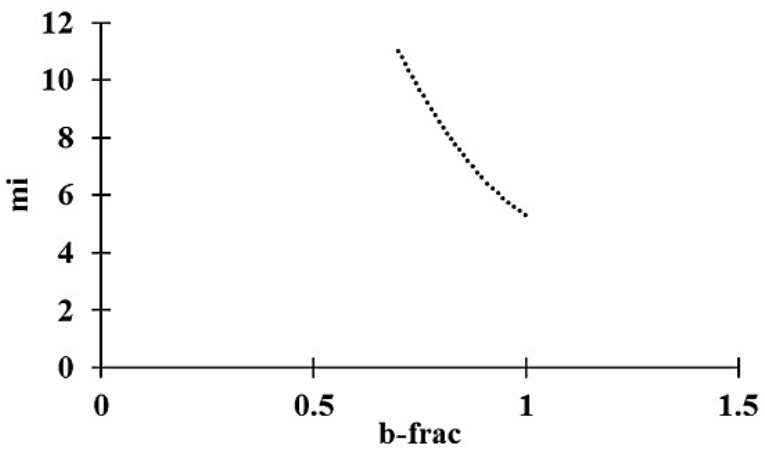

(e)

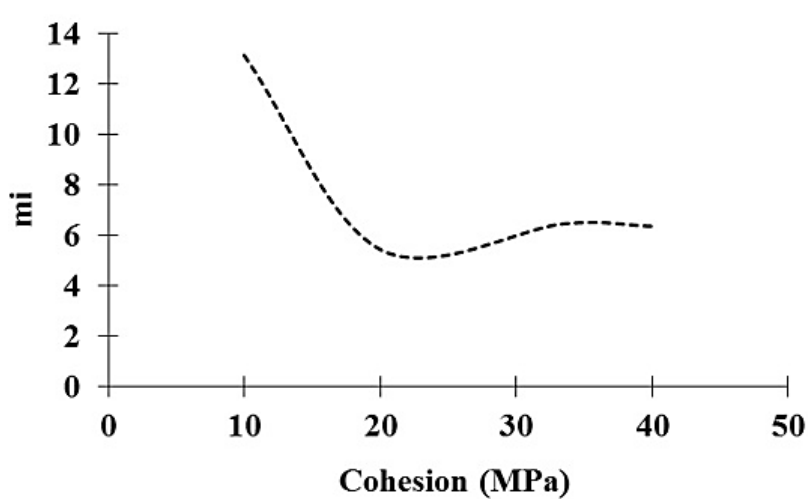

(b)

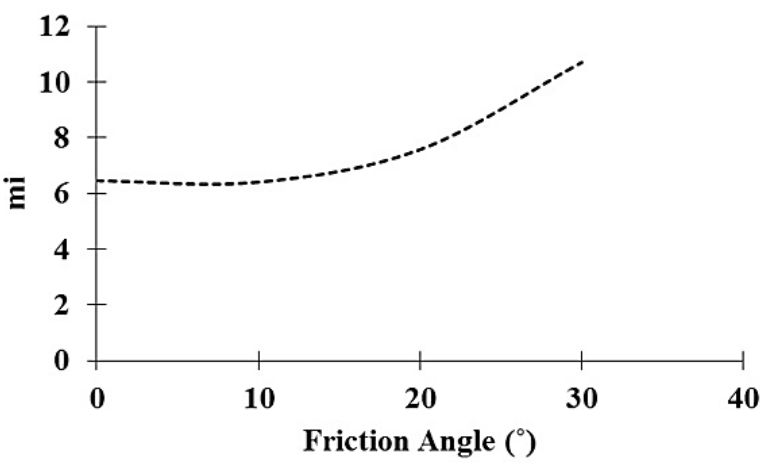

(d)

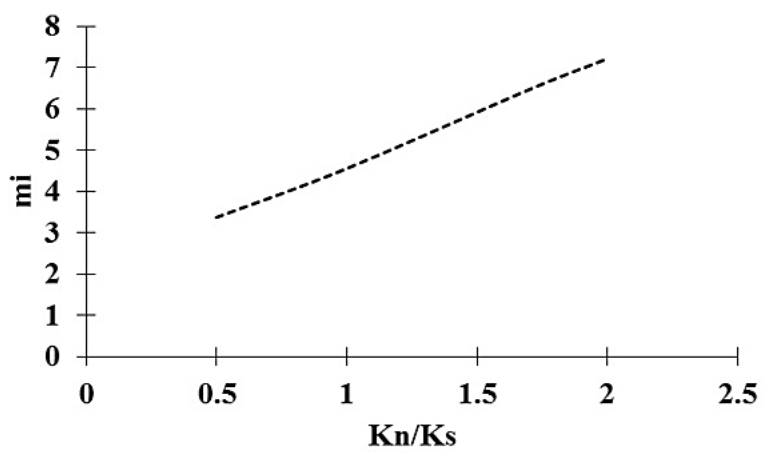

(f)

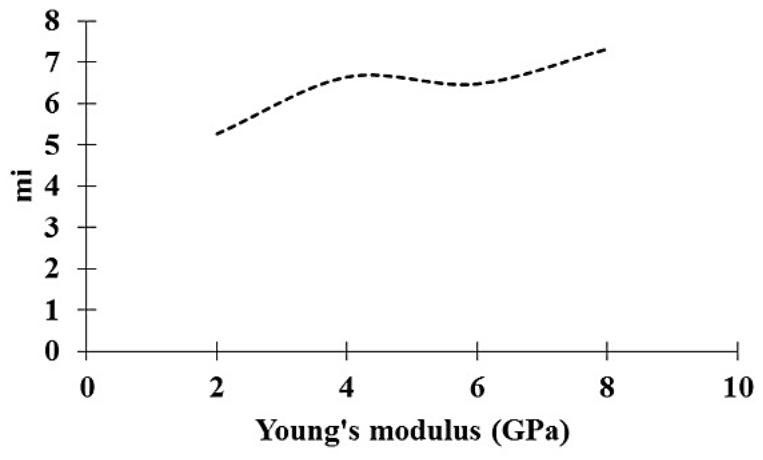

(g)

Figure 3: Effects of micro-parameters on H-B parameter $m_{i}$ in andesite: (a) bond tensile strength, (b) bond cohesion, (c) the friction coefficient, (d) the friction angle, (e) bond fraction (f) the contact stiffness ratio and (g) the particle contact modulus. 


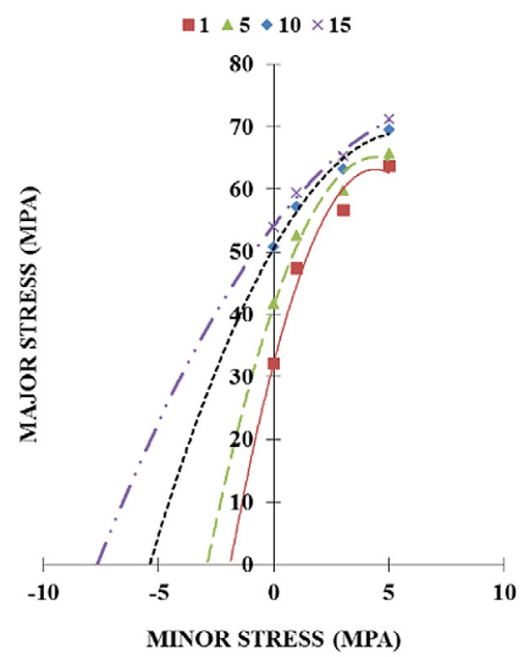

(a)

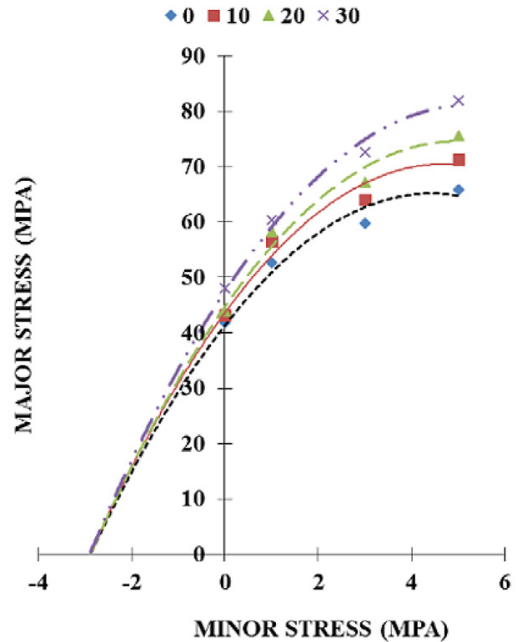

(d)

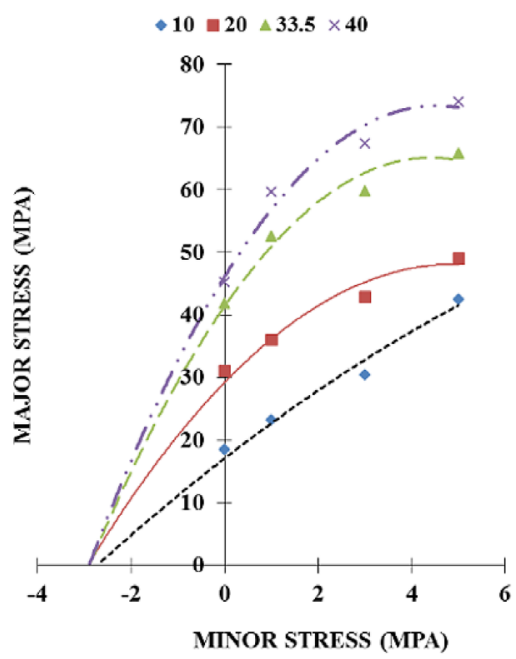

(b)

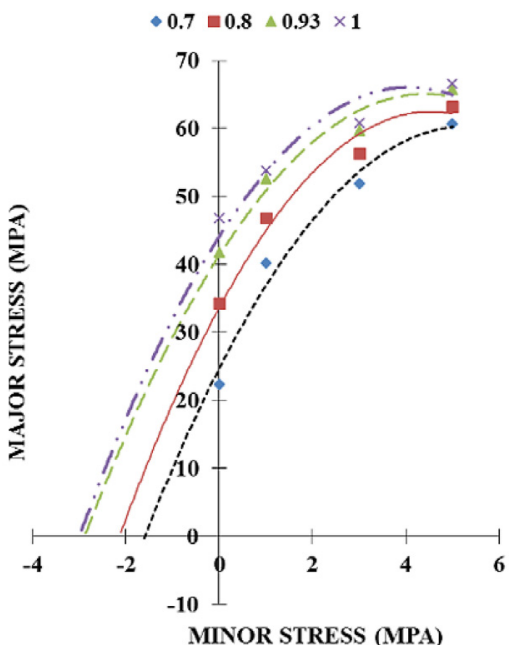

(e)

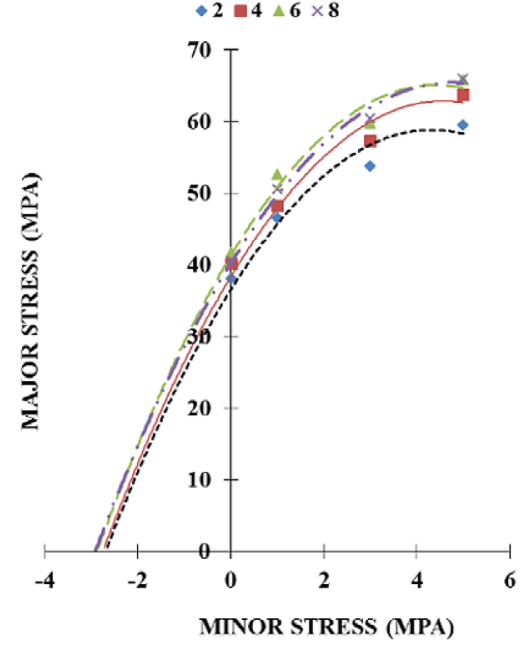

(g)

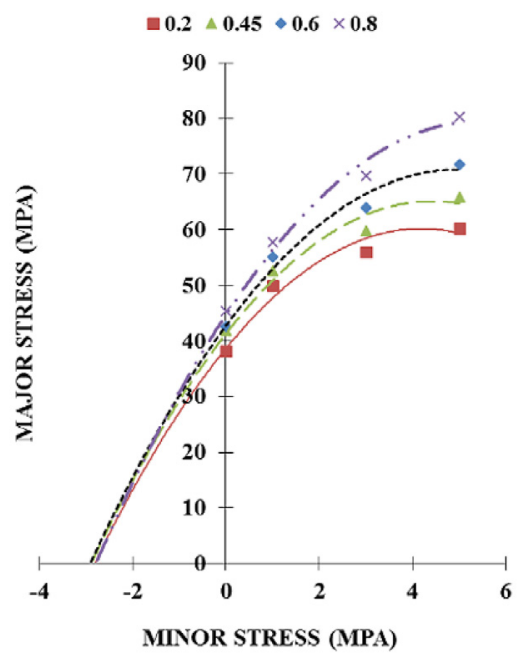

(c)

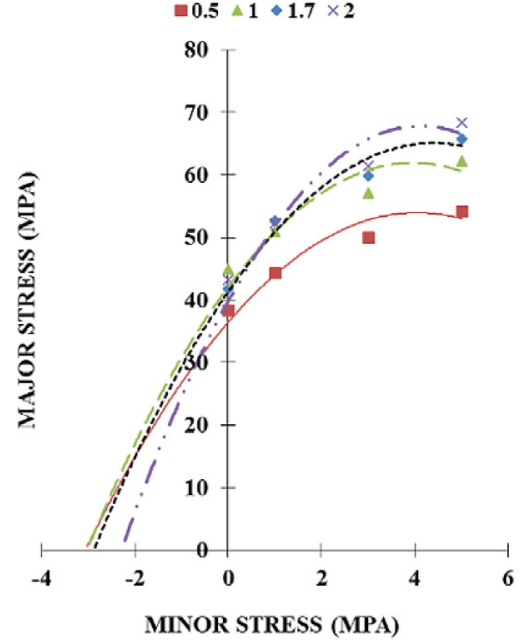

(f)

Figure 4: Effects of micro-parameters on H-B envelope failure in andesite: (a) bond tensile strength, (b) bond cohesion, (c) the friction coefficient, (d) the friction angle, (e) bond fraction (f) the contact stiffness ratio and (g) the particle contact modulus.

can be seen that increasing the amount of the micro-parameter of bond tensile strength leads to a decrease in the value of the $m_{i}$ parameter, so that its value has changed from 16 to 7 , which reached about half of its value. By increasing the micro-parameter of bond cohesion, $m_{i}$ changed slightly at first $(40 \mathrm{MPa}<\mathrm{C}<60 \mathrm{MPa})$, 


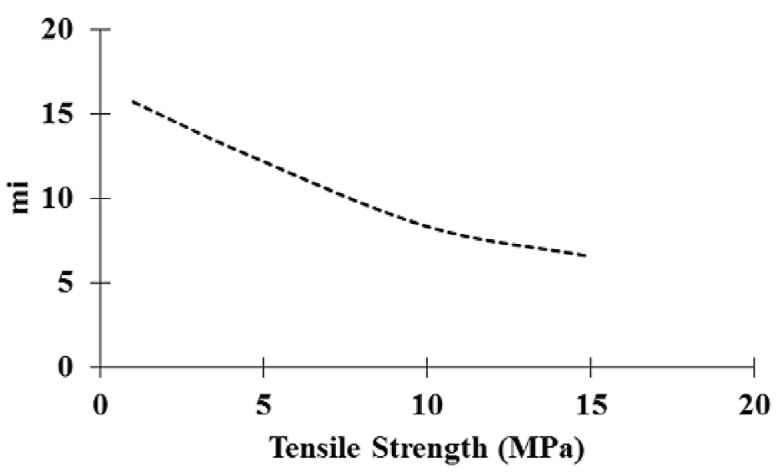

(a)

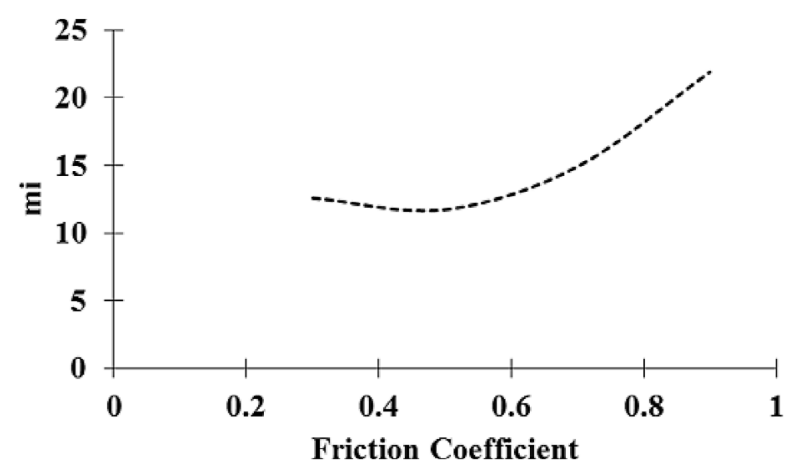

(c)

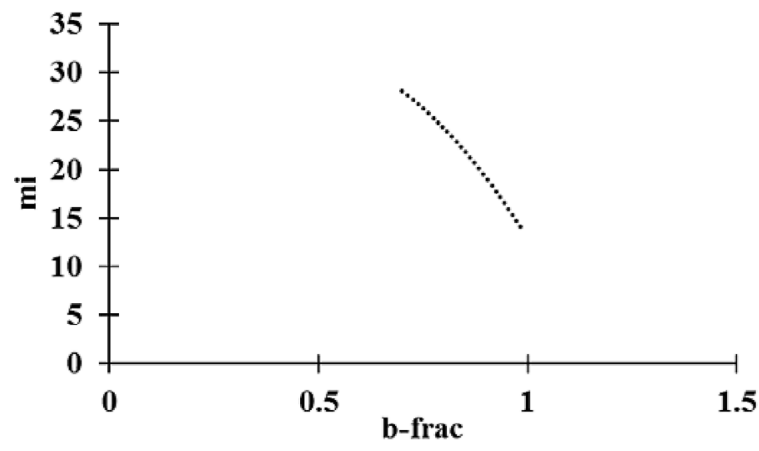

(e)

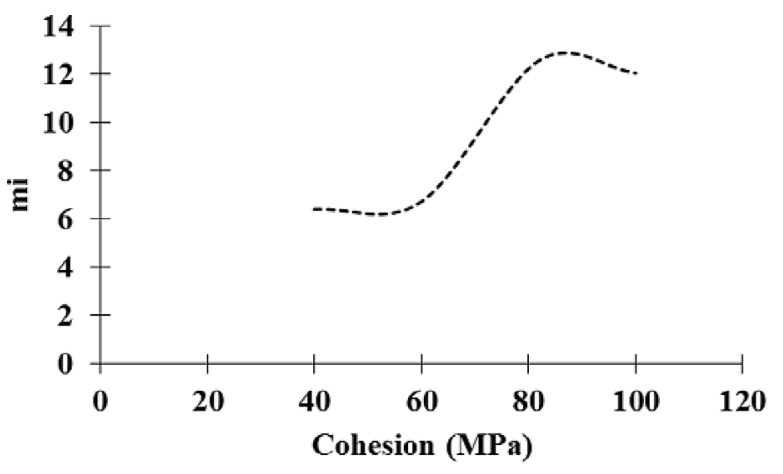

(b)

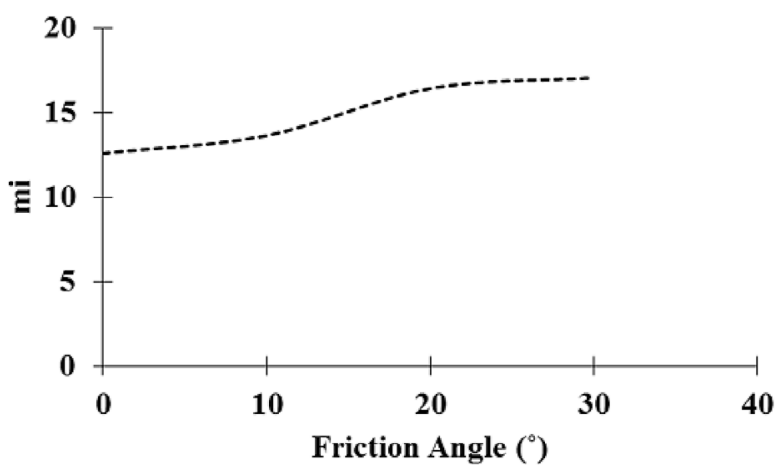

(d)

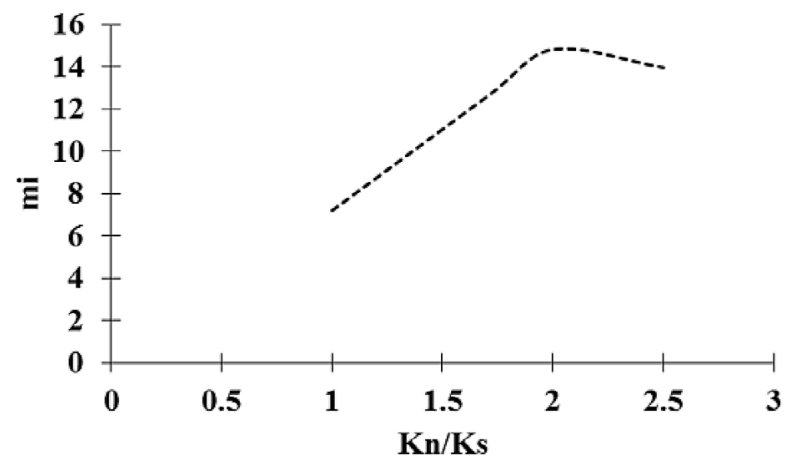

(f)

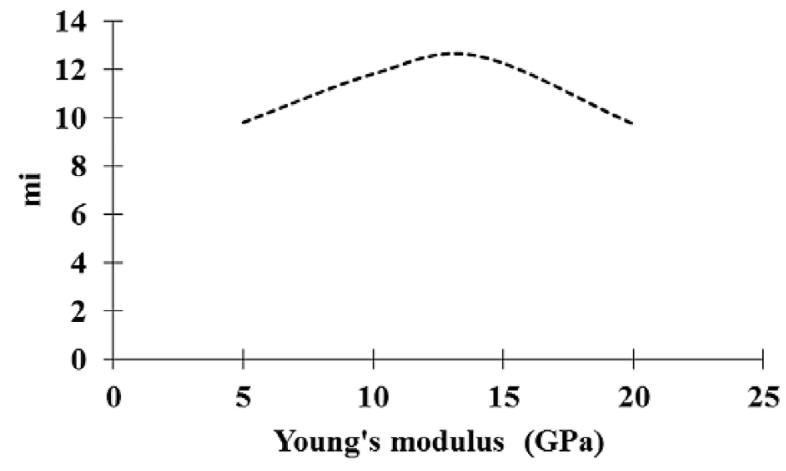

(g)

Figure 5: Effects of micro-parameters on H-B parameter $m_{i}$ in sandstone: (a) bond tensile strength, (b) bond cohesion, (c) the friction coefficient, (d)the friction angle, (e) bond fraction (f) the contact stiffness ratio and (g) the particle contact modulus. 


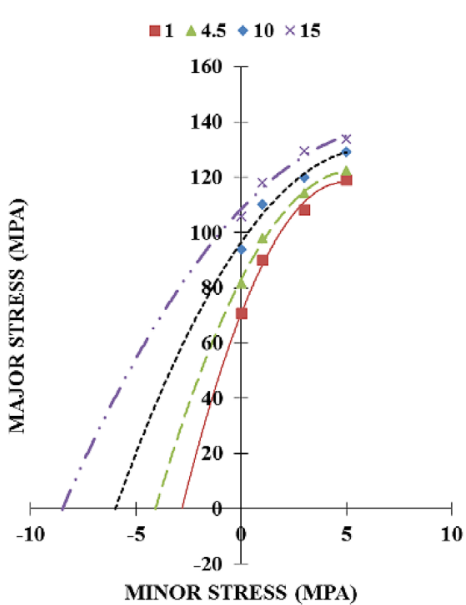

(a)

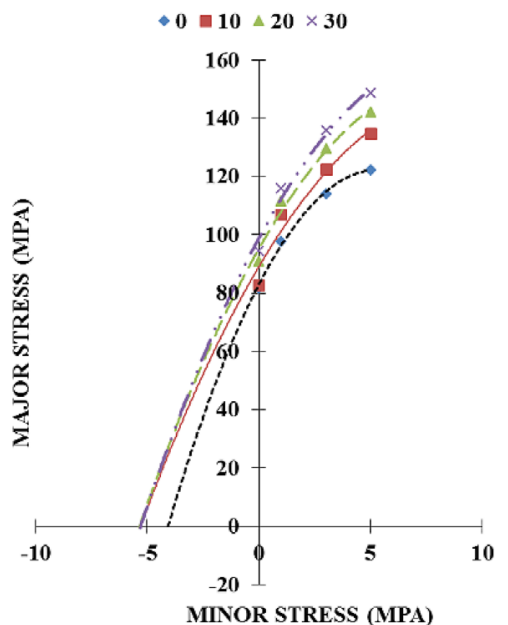

(d)

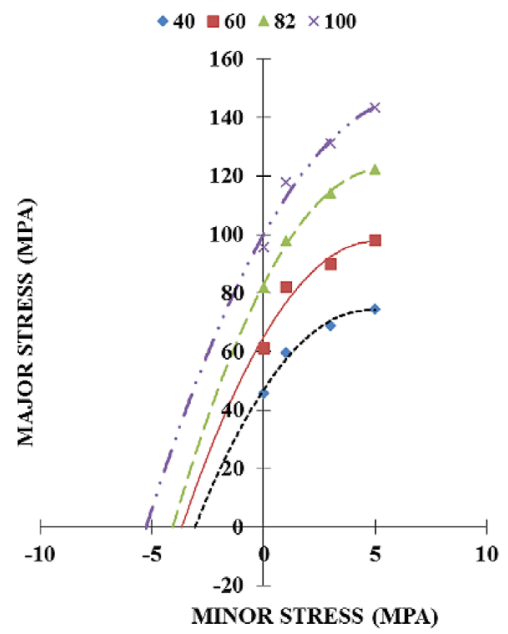

(b)

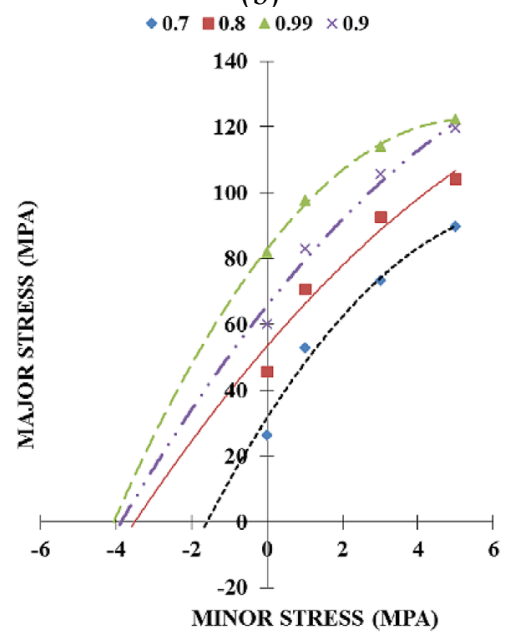

(e)

- $5=10 \Delta 14 \times 20$

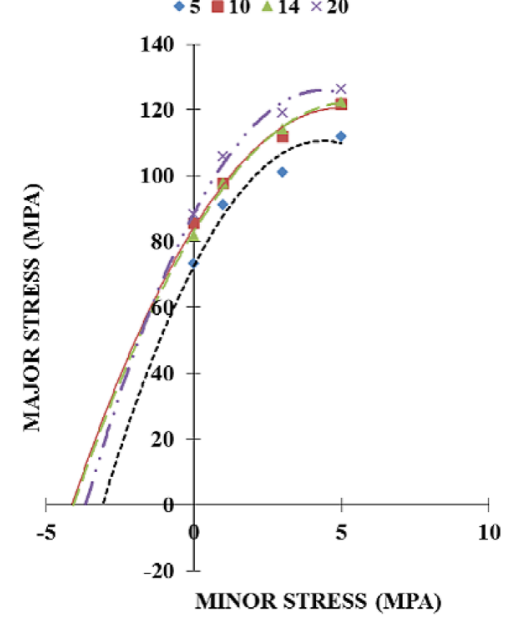

(g)

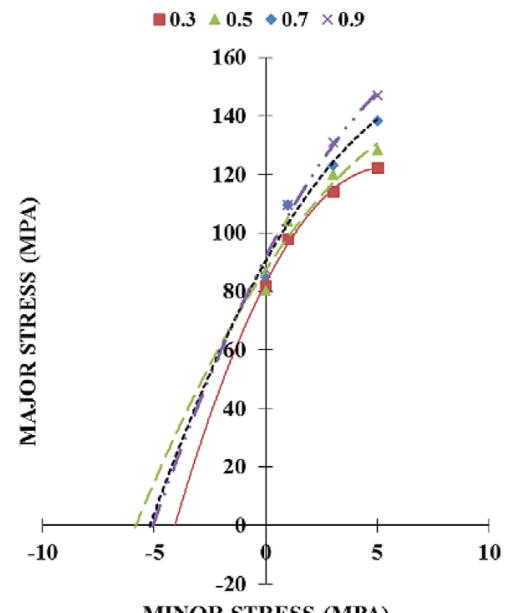

(c)

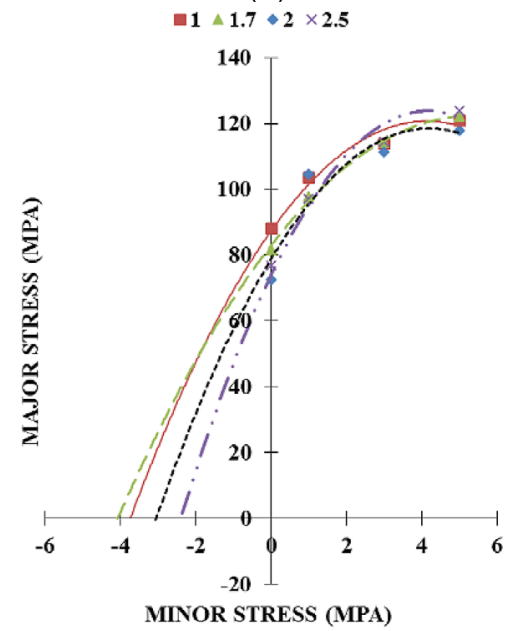

(f) 


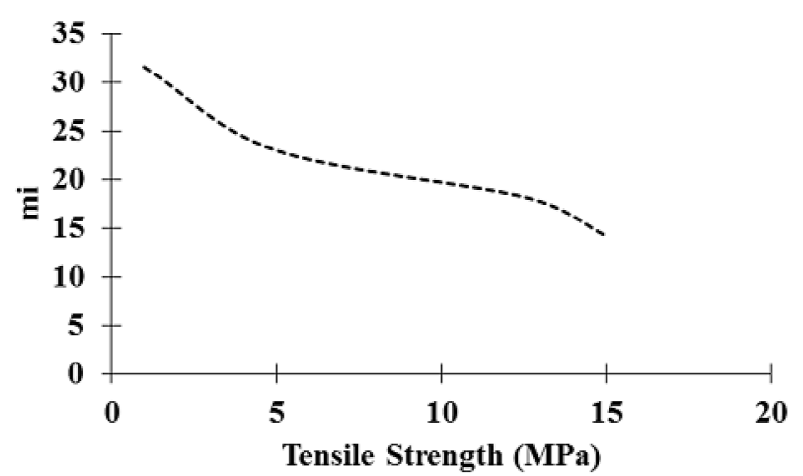

(a)

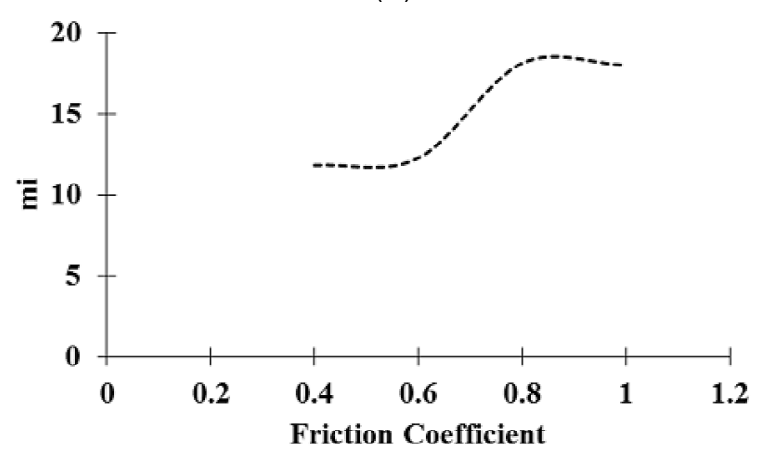

(c)

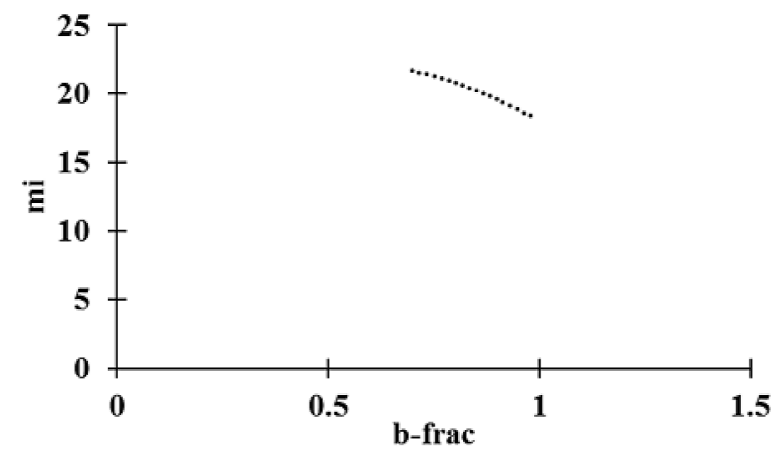

(e)

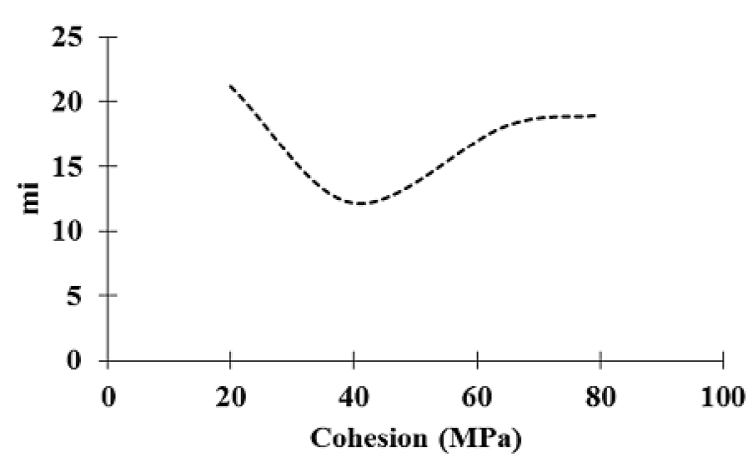

(b)

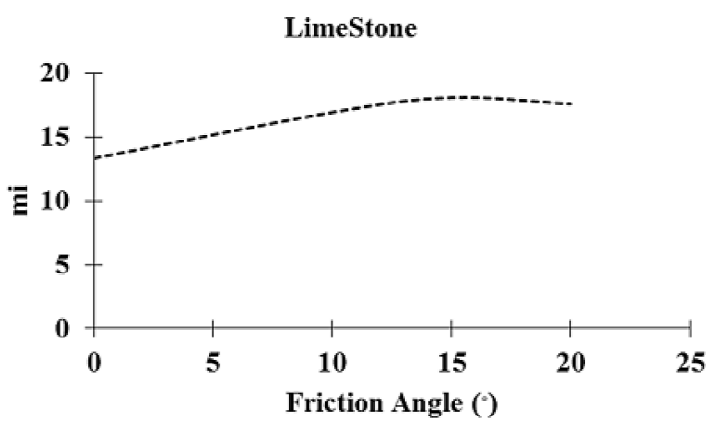

(d)

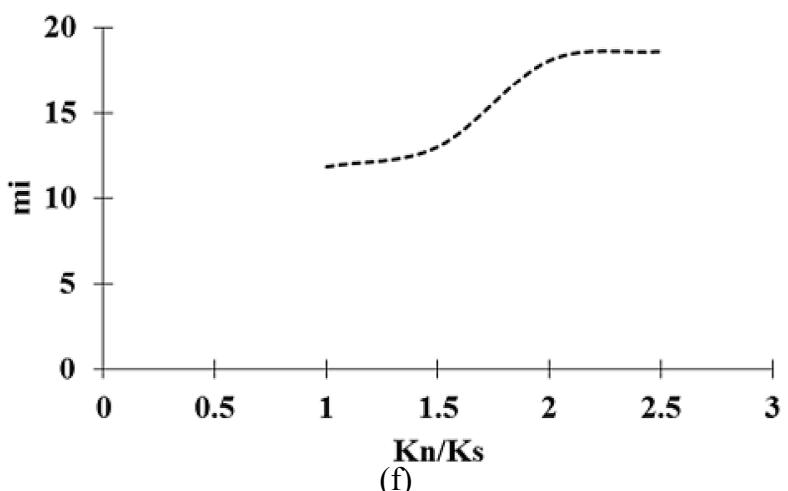

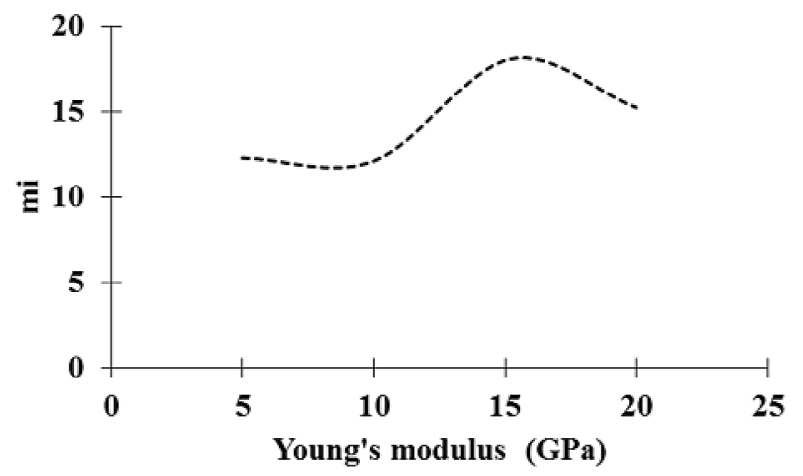

(g)

Figure 7: Effects of micro-parameters on the H-B parameter $m_{i}$ in limestone: (a) bond tensile strength, (b) bond cohesion, (c) the friction coefficient, $(\mathrm{d})$ the friction angle, (e) bond fraction (f) the contact stiffness ratio and (g) the particle contact modulus.

rameter lead to a reduction in the values of the $m_{i}$ parameter. This reduction is linear and the $m_{i}$ changes ranged from 27 to 13. By increasing the amount of the bond stiffness ratio, which varied from 1 to $2.5, m_{i}$ first increased $\left(1<\mathrm{K}_{\mathrm{N}} / \mathrm{K}_{\mathrm{S}}<2\right)$ and then the changes decreased slightly $\left(\mathrm{K}_{\mathrm{N}} / \mathrm{K}_{\mathrm{S}}>2\right)$. With an increase in the value of the 


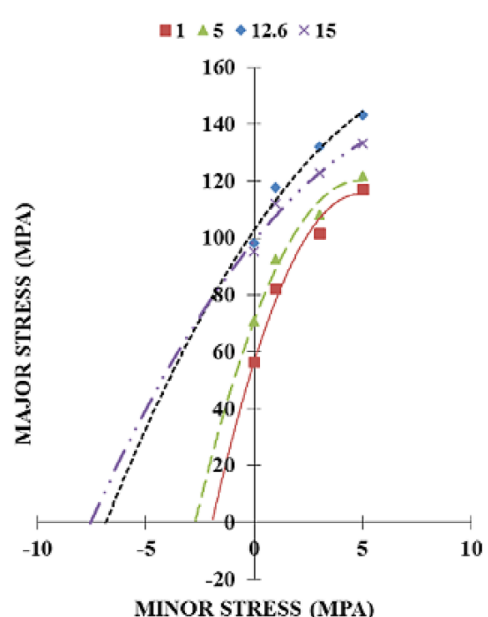

(a)

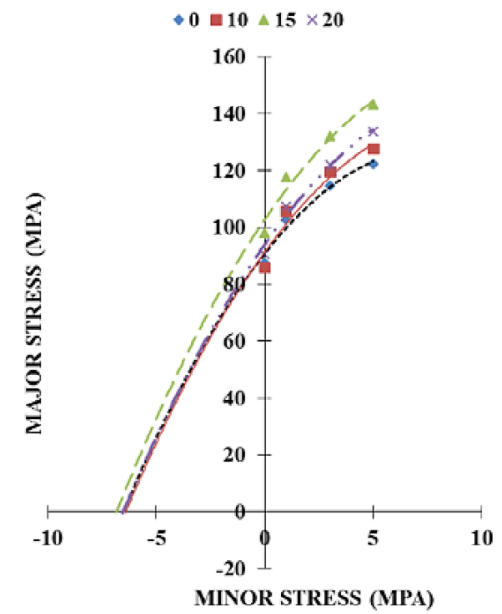

(d)

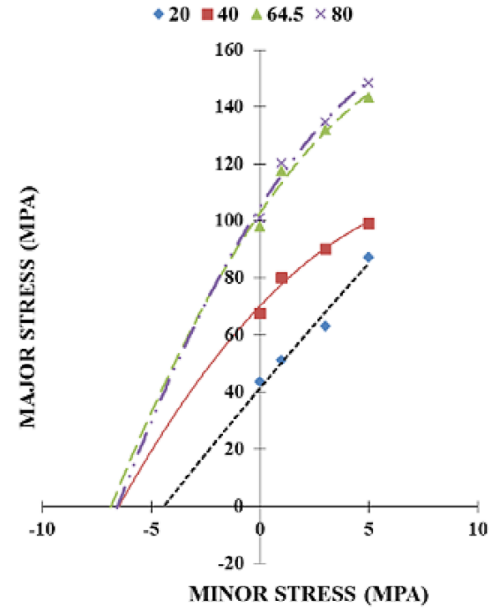

(b)

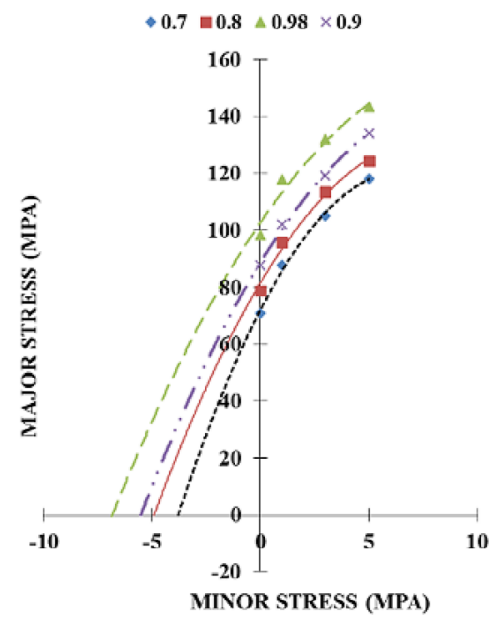

(e)

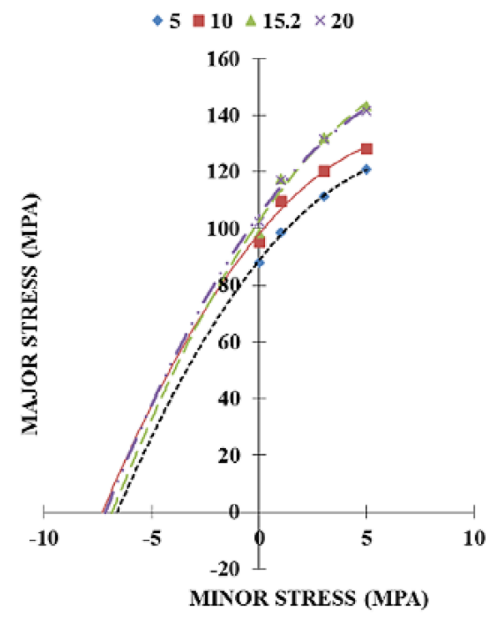

(g)

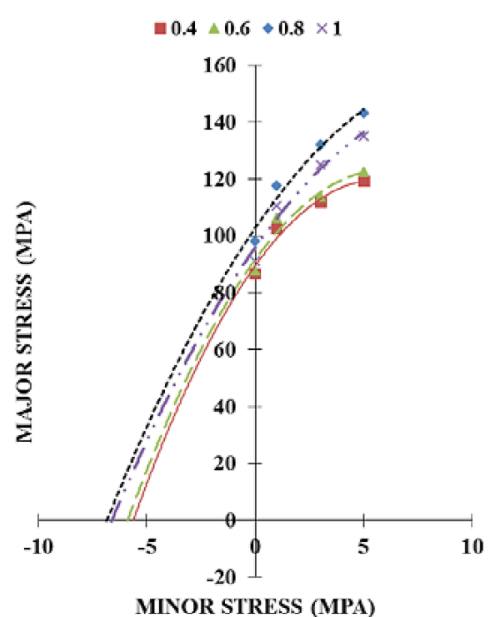

(c)

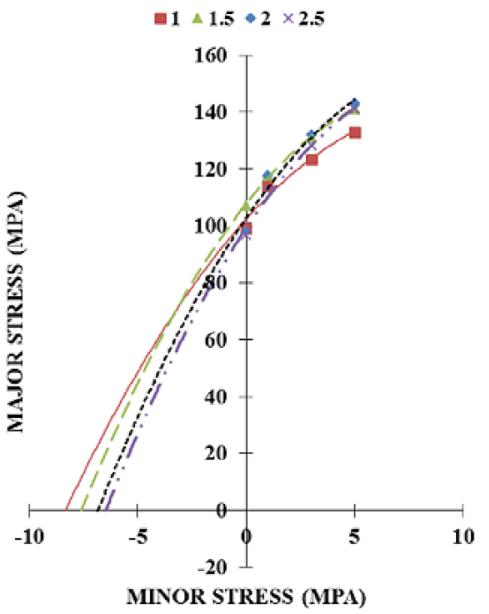

(f) 
of the rock. The bond fraction and the particle contact modulus increased both the maximum and minimum stresses. Also, the stiffness ratio micro-parameter affected both major and minor stresses, but the greatest effect occurred on the minor one.

\subsection{Limestone}

The results of studies on limestone samples are shown in Figures 7 and $\mathbf{8}$. According to Figure 7, it can be seen that with an increase in bond tensile strength, the $m_{i}$ parameter decreased so that its value reached half of the original value (it changed from 32 to 15 ). With an increase in bond cohesion, the $m_{i}$ parameter first decreased $(20 \mathrm{MPa}<\mathrm{C}<40 \mathrm{MPa})$, then it increased $(40 \mathrm{MPa}<\mathrm{C}$ $<65 \mathrm{MPa}$ ) and finally decreased again. Increasing the friction coefficient, which varied from 0.4 to 1 , led to an increase in the $m_{i}$ parameter so that the value of $m_{i}$ changed from 12 to 18 . The rate of changes in $m_{i}$ parameter were small at first ( 0.4 to 0.6 ), then these changes increased ( 0.6 to 0.8$)$ and finally decreased again. As the friction angle increased, $m_{i}$ also increased. However, the rate of this changes was relatively low. By increasing the amount of bond fraction micro-parameter, which varied from 0.7 to 1 , the $m_{i}$ parameter decreased. This reduction was linear and the $m_{i}$ changes ranged from 22 to 17 . Increasing the stiffness ratio also led to an increase in the value of the $m_{i}$ parameter. The changes of the $m_{i}$ parameter were small at first $\left(1<\mathrm{K}_{\mathrm{N}} / \mathrm{K}_{\mathrm{S}}<1.5\right)$, then increased $\left(1.5<\mathrm{K}_{\mathrm{N}} / \mathrm{K}_{\mathrm{S}}<2\right)$ and finally became small again. Moreover, by increasing the amount of particle contact modulus, $m_{i}$ first increased slightly $\left(\mathrm{E}_{\mathrm{c}}<15\right)$, and then the $m_{i}$ value decreased again.

According to Figure 8, it can be seen that similar to the earlier samples, the greatest effect of the bond tensile strength micro-parameter was on the minor stress and its effect on the major stress was relatively smaller. Increasing the micro-parameter of bond cohesion and bond fraction increased the major and minor stress of the limestone. The micro-parameters of friction coefficient and friction angle affected the major stress of the rock. Also, the effect of these micro-parameters on the minor one were very minimal. Increasing the micro-parameter stiffness ratio increased the major stress. This parameter also led to a reduction in minor stress, which is lower in higher values. Also, increasing the micro-parameter of the particle contact modulus increased the major and minor stresses, and these changes were greater than in the major stresses.

\section{Conclusion}

In this paper, using numerical simulations of triaxial compressive strength tests in PFC-2D code, the effects of micro-parameters in rocks on the H-B parameter $m_{i}$ were researched. To perform the analyses, the mechanical behaviour of three different rock types: andesite, sandstone and limestone, have been simulated and the effects of micro-parameters of bond tensile strength, bond cohesion, the friction coefficient, the friction angle, bond fraction, the particle contact modulus (Ec) and the contact stiffness ratio $(\mathrm{Kn} / \mathrm{Ks})$ have been evaluated. According to the performed analyses, the results of this research can be summarized as follows:

- The $m_{i}$ parameter of the H-B criterion has an inverse relationship to the micro-parameters of bond tensile strength and bond fraction of the rocks, so that by increasing these micro-parameters, the $m$ parameter decreases by about half of its original value.

- The effects of the bond cohesion micro-parameter on $m_{i}$ is varied in different rocks.

- The $m_{i}$ parameter increases with an increase in the micro-parameters of the friction coefficient, the friction angle, the particle contact modulus, and the contact stiffness ratio of rocks. However, these effects vary depending on the type of rock.

- The greatest effect of the bond tensile strength micro-parameter was on the minor stress and its effect on the major stress is relatively smaller.

- The greatest effects of micro-parameters of the friction coefficient and the friction angle was on the major stress and their effects on a minor one are very small.

- Increasing the amount of the contact stiffness ratio micro-parameter reduces the minor stress in different rocks.

\section{Reference}

Akram, M. S., \& Sharrock, G. B. (2010): Physical and numerical investigation of a cemented granular assembly of steel spheres. International Journal for Numerical and Analytical Methods in Geomechanics, 34, 18, 1896-1934. https://doi.org/10.1002/nag.885.

Aladejare, A. E., \& Wang, Y. (2019): Probabilistic characterization of Hoek-Brown constant mi of rock using Hoek's guideline chart, regression model and uniaxial compression test. Geotechnical and Geological Engineering, 37, 6, 5045-5060. https://doi.org/10.1007/s10706-019-00961-7.

Asadi, M., Rasouli, V., \& Barla, G. (2012): A bonded particle model simulation of shear strength and asperity degradation for rough rock fractures. Rock Mechanics and Rock Engineering, 45, 5, 649-675. https://doi.org/10.1007/ s00603-012-0231-4.

Bagheripour, M. H., \& Hakimipour, R. (2009): Evaluating the efficiency of the Hoek-Brown failure criterion in predicting strength of rock mass for dam foundations and tunnels. In Proc. 1st National Conference on Engineering and Infrastructure Managements, 27-29.

Bahaaddini, M., Sharrock, G., \& Hebblewhite, B. K. (2013a): Numerical direct shear tests to model the shear behavior of rock joints. Computers and Geotechnics, 51, 101-115. https://doi.org/10.1016/j.compgeo.2013.02.003. 
Bahaaddini, M., Sharrock, G., \& Hebblewhite, B. K. (2013b): Numerical investigation of the effect of joint geometrical parameters on the mechanical properties of a non-persistent jointed rock mass under uniaxial compression. Computers and Geotechnics, 49, 206-225. https://doi. org/10.1016/j.compgeo.2012.10.012.

Bahaaddini, M., Hagan, P. C., Mitra, R., \& Hebblewhite, B. K. (2014): Scale effect on the shear behavior of rock joints based on a numerical study. Engineering Geology, 181, 212-223. https://doi.org/10.1016/j.compgeo.2012.10.012.

Bahaaddini, M., Hagan, P. C., Mitra, R., \& Hebblewhite, B. K. (2016): Numerical study of the mechanical behaviour of non-persistent jointed rock masses. International Journal of Geomechanics, 16, 1, 04015035-040150310. https:// doi.org/10.1061/(ASCE)GM.1943-5622.0000510.

Bahaaddini, M. (2017): Effect of boundary condition on the shear behavior of rock joints in the direct shear test. Rock Mechanics and Rock Engineering, 50, 5, 1141-1155. https://doi.org/10.1007/s00603-016-1157-z.

Bahaaddini, M., Sheikhpourkhani, A. M., \& Mansouri, H. (2019): Flat-joint model to reproduce the mechanical behavior of intact rocks. European Journal of Environmental and Civil Engineering. 25, 8, 1-22. https://doi.org/10.1080 $/ 19648189.2019 .1579759$.

Bertuzzi, R., Douglas, K., \& Mostyn, G. (2016): Comparison of quantified and chart GSI for four rock masses. Engineering Geology, 202, 24-35. https://doi.org/10.1016/j. enggeo.2016.01.002.

Calvetti, F. (2008): Discrete modeling of granular materials and geotechnical problems. European Journal of Environmental and Civil Engineering, 12, 7-8, 951-965. https:// doi.org/10.1080/19648189.2008.9693055.

Colak, K., \& Unlu, T. (2004): Effect of transverse anisotropy on the Hoek-Brown strength parameter 'mi' for intact rocks. International journal of rock mechanics and mining sciences, 41, 6, 1045-1052.

Cui, Z., Sheng, Q., Leng, X., \& Ma, Y. (2017): investigation of the long-term strength of Jinping marble rocks with experimental and numerical approaches. Bulletin of Engineering Geology and the Environment. 78, 877-882. https://doi:10.1007/s10064-017-1132-2.

Deisman, N., Mas Ivars, D., Darcel, C., \& Chalaturnyk, R. J. (2010): Empirical and numerical approaches for geomechanical characterization of coal seam reservoirs. International Journal of Coal Geology, 82, 34, 204-212. https:// doi.org/10.1016/j.coal.2009.11.003.

Feng, X., \& Jimenez, R. (2015): Estimation of deformation modulus of rock masses based on Bayesian model selection and Bayesian updating approach. Engineering Geology, 199, 19-27. https://doi.org/10.1016/j.enggeo.2015.10.002.

Ghazvinian, A., Sarfarazi, V., Schubert, W., \& Blumel, M. (2012): A study of the failure mechanism of planar nonpersistent open joints using PFC2D. Rock mechanics and rock engineering, 45, 5, 677-693.

Gu, X., Li, W., Qian, J., \& Xu, K. (2017): Discrete element modeling of the influence of inherent anisotropy on the shear behavior of granular soils. European Journal of Environmental and Civil Engineering, 22, 1-18. https://doi.or $\mathrm{g} / 10.1080 / 19648189.2017 .1352030$.
Haeri, H., \& Sarfarazi, V. (2016): Numerical simulation of tensile failure of concrete using particle flow code (PFC). Computers and Concrete, 18, 1, 53-68.

Hama, N. A., Ouahbi, T., Taibi, S., Souli, H., Fleureau, J. M., \& Pantet, A. (2017): Relationships between the internal erosion parameters and the mechanical properties of granular materials. European Journal of Environmental and Civil Engineering, 1-13. https://doi.org/10.1080/19648189 .2017.1347526.

He, M., Zhang, Z., Zheng, J., Chen, F., \& Li, N. (2020): A New Perspective on the Constant mi of the Hoek-Brown Failure Criterion and a New Model for Determining the Residual Strength of Rock. Rock Mechanics and Rock Engineering, 53, 3953-3967. https://doi.org/10.1007/s00603020-02164-6.

Hoek, E., \& Brown, E. T. (1980a): Empirical strength criteria for rock masses. J. Geotech. Eng. Div., Am. Soc. Civ. Eng.; (United States), 106, 1013-1035.

Hoek, E., \& Brown, E. T. (1980b): Underground Excavations in Rock, London, Instn Min. Metallurgy, 527.

Hoek, E. (1983): Strength of jointed rock masses. Geotechnique, 33, 3, 187-223.

Hoek, E., (2007): Practical rock engineering. Institution of Mining and Metallurgy, London, 198-200.

Jafari Mohammadabadi, B., Shahriar, K., Jalalifar, H., \& Ahangari, K. (2021): An investigation on the effects of micro-parameters on the strength properties of rock. Rudarsko-geološko-naftni zbornik (The Mining-GeologyPetroleum Engineering Bulletin), 36, 1, 111-119. https:// doi.org/10.17794/rgn.2021.1.9.

Jiang, X. Y., Cui, P., \& Liu, C. Z. (2016): A chart-based seismic stability analysis method for rock slopes using HoekBrown failure criterion. Engineering Geology, 209, 196208. https://doi.org/10.1016/j.enggeo.2016.05.015.

Jiang, M., Liao, Y., Wang, H., \& Sun, Y. (2018): Distinct element method analysis of jointed rock fragmentation induced by TBM cutting. European Journal of Environmental and Civil Engineering, 22, 1, 79-98. https://doi.org/10. 1080/19648189.2017.1385540.

Lin, H., Wang, H., Fan, X., Cao, P., \& Zhou, K. (2017): Particle size distribution effects on deformation properties of graded aggregate base under cyclic loading. European Journal of Environmental and Civil Engineering, 1-18. https://doi.org/10.1080/19648189.2016.1276480.

Mas Ivars, D., Pierce, M. E., Darcel, C., Reyes-Montes, J., Potyondy, D. O., Young, R. P., \& Cundall, P. A. (2011): The synthetic rock mass approach for jointed rock mass modelling. International Journal of Rock Mechanics \& Mining Sciences, 48, 2, 219-244. https://doi.org/10.1016/j. ijrmms.2010.11.014.

Merifield, R. S., Lyamin, A. V., \& Sloan, S. W. (2006): Limit analysis solutions for the bearing capacity of rock masses using the generalised Hoek-Brown criterion. International Journal of Rock Mechanics and Mining Sciences, 43, 6, 920-937. https://doi.org/10.1016/j.ijrmms.2006.02.001.

Osgoui, R. R., \& Ünal, E. (2009): An empirical method for design of grouted bolts in rock tunnels based on the Geological Strength Index (GSI). Engineering geology, 107, 3-4, 154166. https://doi.org/10.1016/j.enggeo.2009.05.003. 
Peng, J., Cai, M., Rong, G., Yao, M. D., Jiang, Q. H., \& Zhou, C. B. (2017): Determination of confinement and plastic strain dependent post-peak strength of intact rocks. Engineering Geology, 218, 187-196. https://doi.org/10.1016/j. enggeo.2017.01.018.

Potyondy, D. O., \& Cundall, P. A. (2004): A bonded-particle model for rock. International journal of rock mechanics and mining sciences, 41, 8, 1329-1364. https://doi.org/ 10.1016/j.ijrmms.2004.09.011.

Sarfarazi, V., Ghazvinian, A., Schubert, W., Blumel, M., \& Nejati, H. R. (2014): Numerical simulation of the process of fracture of echelon rock joints. Rock Mechanics and Rock Engineering, 47, 4, 1355-1371.

Sarfarazi, V., Haeri, H., Marji, M. F., \& Zhu, Z. (2017): Fracture mechanism of Brazilian discs with multiple parallel notches using PFC2D. Periodica Polytechnica Civil Engineering, 61, 4, 653-663.

Sari, M. (2010): A Simple Approximation to Estimate the Hoek-Brown Parameter "mi” For Intact Rocks. ISRM International Symposium-EUROCK. International Society for Rock Mechanics and Rock Engineering.

Sari, M. (2012): An improved method of fitting experimental data to the Hoek-Brown failure criterion. Engineering geology, 127, 27-35. https://doi.org/10.1016/j.enggeo.2011. 12.011.

Shah, S., \& Hoek, E. (1992): Simplex reflection analysis of laboratory strength data. Canadian Geotechnical Journal, 29, 2, 278-287.

Shen, J., Karakus, M., \& Xu, C. (2013): Chart-based slope stability assessment using the Generalized Hoek-Brown criterion. International Journal of Rock Mechanics and
Mining Sciences, 64, 210-219. https://doi.org/10.1016/j. ijrmms.2013.09.002.

Sun, C., Chai, J., Xu, Z., Qin, Y., \& Chen, X. (2016): Stability charts for rock mass slopes based on the Hoek-Brown strength reduction technique. Engineering Geology, 214, 94-106. https://doi.org/10.1016/j.enggeo.2016.09.017.

Wang, W., \& Shen, J. (2017): Comparison of existing methods and a new tensile strength based model in estimating the Hoek-Brown constant mi for intact rocks. Engineering Geology, 224, 87-96. https://doi.org/10.1016/j.enggeo. 2017.05.008.

Wen, T., Tang, H., Huang, L., Hamza, A., \& Wang, Y. (2021): An empirical relation for parameter mi in the Hoek-Brown criterion of anisotropic intact rocks with consideration of the minor principal stress and stress-to-weak-plane angle. Acta Geotechnica, 16, 2, 551-567. https://doi.org/10.1007/ s11440-020-01039-y.

Wu, Z., Fan, L., Liu, Q., \& Ma, G. (2017): Micro-mechanical modeling of the macro-mechanical response and fracture behavior of rock using the numerical manifold method. Engineering Geology, 225, 49-60. https://doi.org/10.1016/j. enggeo.2016.08.018.

Yang, S. Q., \& Huang, Y. H. (2018): Failure behaviour of rocklike materials containing two pre-existing unparallel flaws: an insight from particle flow modeling. European Journal of Environmental and Civil Engineering, 22, 1, 57-78. https://doi.10.1080/19648189.2017.1366954.

Zhang, Q., Zhu, H. H., \& Zhang, L. (2014): Studying the effect of non-spherical micro-particles on Hoek-Brown strength parameter mi using numerical true triaxial compressive tests. International Journal for Numerical and Analytical Methods in Geomechanics, 39, 1, 96-114. https://doi. org/10.1002/nag.2310.

\section{SAŽETAK}

\section{Varijacija intrinističkih svojstava stijene u ovisnosti o Hoek-Brownovim parametrima kriterija loma}

Hoek-Brownov kriterij (HB) jedan je od najčešće korištenih kriterija loma stijena posljednjih godina. Ovaj kriterij uključuje konstantni parametar zvan $m_{i}$ koji je temeljni parametar za procjenu čvrstoće stijene. Zbog važnosti parametra $m_{i} u$ Hoek-Brownovu kriteriju potrebno je provesti sveobuhvatne studije o različitim aspektima učinka ovoga parametra na ponašanje stijena. Stoga su u ovoj studiji, korištenjem numeričke simulacije ispitivanja troosne tlačne čvrstoće (TCS) u PFC-2D kodu, proučavani učinci mikroskopskih svojstava različitih stijena na Hoek-Brownov parametar $m_{i}$. Na temelju rezultata ove studije utvrđeno je da učinci mikroparametara na Hoek-Brownov parametar $m_{i}$ mogu biti različiti, ovisno o vrsti stijene, međutim ovaj parametar ima obrnut odnos prema mikroparametrima vlačne čvrstoće veze i veza frakcija stijena. Također, parametar $m_{i}$ raste s povećanjem mikroparametara koeficijenta trenja, kuta trenja, modula kontakta čestica i odnosa krutosti stijena.

Ključne riječi:

Hoek-Brownov kriterij, parametar $m_{i}$, troosna tlačna čvrstoća, mikroskopska svojstva, PFC-2D

\section{Author's contribution}

Sina Salajegheh (Ph.D. student): author and performer of numerical tests. Shahriar (Full Professor): interpretation and analysis of numerical and laboratory results. Jalalifar (Full Professor): ideation and monitored the execution of work from beginning to end. Ahangari (Assistance Professor): assistance in writing and history of literature. 